\title{
PENGARUH KONSENTRASI STARTER BAKTERI Lactobacillus plantarum TERHADAP BEBERAPA KOMPONEN MUTU TEPUNG PORANG (Amorphophallus oncophyllus)
}

\author{
[The Effect of Lactobacillus plantarum Bacteria Starter Concentration on Some \\ Quality of the Porang Flour (Amorphophallus oncophyllus)] \\ Ade Irma Juliana ${ }^{1 *}$, Nazaruddin ${ }^{2)}$ dan Moegiratul Amaro ${ }^{2)}$ \\ 1)Mahasiswa Fakultas Teknologi Pangan dan Agroindustri Universitas Mataram \\ ${ }^{2)}$ Staf Pengajar Fakultas Teknologi Pangan dan Agroindustri Universitas Mataram \\ Jl. Majapahit No. 58 Mataram \\ Email: adeirmajuliana@gmail.com
}

Diterima 28 Agustus 2020 / Disetujui 07 Januari 2021

\begin{abstract}
This study aims to determine the effect of Lactobacillus plantarum bacterial starter concentration on some quality of the porang flour. This study used experimental design one-factor Completely Randomized Design (CRD) consisted of BAL concentration (KB) of Lactobacillus plantarum with 6 treatments which is $0 \%$, $5 \%, 10 \%, 15 \%, 20 \%$ and $25 \%$. Each of treatment were repeated three times to obtain 18 unit samples. Data from observations were analyzed using analysis of variance (Analysis of Variance) at 5\% significance level using Co-stat software. If there are significant differences, a further Polynomial Orthogonal and Honestly Significant Difference (BNJ) test is performed at a level of $5 \%$. The parameters observed included $\mathrm{pH}$ value, protein content, water content, yield, total lactic acid bacteria, organoleptic parameters of color and aroma (hedonic and scoring). The results showed that the concentration of Lactobacillus plantarum bacterial $20 \%$ was the best treatment in producing porang flour, pH value 5.72, protein content $6.49 \%$, yield $9.33 \%$, total lactic acid bacteria $6.66 \mathrm{log}$ CFU / $g$ and color rather brown and slightly acidic aroma and somewhat preferred by panelists.
\end{abstract}

Keywords: Porang flour, starter concentration, Lactobacillus plantarum

\begin{abstract}
ABSTRAK
Penelitian ini bertujuan untuk mengetahui pengaruh konsentrasi starter bakteri Lactobacillus plantarum terhadap beberapa komponen mutu tepung porang. Penelitian ini menggunakan Rancangan Acak Lengkap (RAL) dengan satu faktor yakni konsentrasi BAL (KB) jenis Lactobacillus plantarum dengan 6 perlakuan yaitu $0 \%, 5 \%, 10 \%, 15 \%, 20 \%$ dan $25 \%$. Masing-masing perlakuan diulang sebanyak 3 kali sehingga diperoleh 18 unit percobaan. Data hasil pengamatan dianalisis menggunakan analisis keragaman (Analysis of Variance) pada taraf nyata $5 \%$ menggunakan software Co-stat. Apabila terdaapat beda nyata, dilakukan uji lanjut Polynomial Orthogonal dan Beda Nyata Jujur (BNJ) pada taraf 5\%. Adapun parameter yang diamati meliputi nilai $\mathrm{pH}$, kadar protein, kadar air, rendemen, total bakteri asam laktat, parameter organoleptik warna dan aroma (hedonik dan scoring). Hasil penelitian menunjukkan bahwa konsentrasi strater bakteri Lactobacillus plantarum $20 \%$ merupakan perlakuan terbaik dalam menghasilkan tepung porang nilai pH 5,72, kadar protein 6,49\%, rendemen 9,33\%, total bakteri asam laktat 6,66 log CFU/g serta warna agak coklat dan aroma agak asam serta agak disukai panelis.
\end{abstract}

Kata Kunci: Tepung porang, konsentrasi starter, Lactobacillus plantarum

\section{PENDAHULUAN}

Indonesia merupakan Negara agraris yang kaya akan hasil komiditi pertanian yang beragam jenisnya dan salah satunya umbiumbian. Umbi-umbian digolongkan menjadi umbi mayor dan minor. Umbi mayor adalah umbi yang produksinya cukup besar dan sudah banyak dimanfaatkan sebagai bahan pangan, sedangkan umbi minor produksinya kecil dan pemanfaatannya masih terbatas. Salah satu umbi yang termasuk umbi minor adalah umbi porang. Menurut Yuzammi (2009) umbi porang (Amorphophallus oncophyllus) yang merupakan salah satu tanaman yang berasal dari genus Amorphophallus yang kini sudah mulai dimanfaatkan oleh masyarakat di daerah Lombok Utara. Namun, pemanfaatannya belum optimal karena data mengenai jenis-jenis tanaman yang berasal dari genus 
Versi Online:

http://www.profood.unram.ac.id/index.php/profood e-ISSN: 2443-3446

Amorphophallus di Pulau Lombok masih sangat kurang.

Menurut Koswara (2006), umbi porang memiliki potensi ekonomi yang cukup tinggi. Hal tersebut dapat dilihat dari kebutuhan negara-negara tetangga seperti Jepang akan umbi porang cukup tinggi. Bukan hanya itu gaplek porang Indonesia juga sangat diminati negara tetangga lainnya seperti Malaysia, Singapura dan China. Umbi porang di Indonesia umumnya diekspor dalam umbi segar atau bentuk chips sebesar 3.000 ton/tahun ke berbagai negara, antara lain Tiongkok, Jepang, dan Taiwan (Santosa, 2014). Selama ini Indonesia mengekspor umbi porang lebih banyak dalam bentuk gaplek (atau chips kering) daripada tepung. Melihat potensi ekonomi umbi porang yang cukup besar tersebut mendorong pemerintah melalui keputusan Gubernur NTB No. 903-600 (2016) menganggarkan biaya untuk pembudidayaan umbi porang sebesar Rp 24.650.000/ha sehingga dapat dihasilkan umbi porang yang cukup besar.

Umbi Porang (Amorphophallus oncophyllus) merupakan salah satu umbi minor yang berpotensi menjadi salah satu pangan pokok alternatif selain beras, singkong, jagung dan gandum dalam memenuhi kebutuhan karbohidrat karena kandungan pati yang cukup tinggi yakni dapat mencapai 77,0\% (Ohtsuki, 1968). Menurut Harijati (2011) umbi porang mempunyai kandungan glukomanan yang cukup tinggi mencapai 5\%-65\%. Glukomanan dalam industri pangan dimanfaatkan sebagai pangan fungsional berupa makanan diet yang rendah lemak dan kalori, pengikat air, bahan pengental, bahan penggumpal atau pembentuk gel karena sifat kelarutan glukomannanya yang tinggi di dalam air sehingga dapat dimanfaatkan sebagai penstabil es krim untuk memperbaiki tekstur (Koswara, 2013). Untuk memudahkannya dalam pengaplikasian dalam industri pangan maka perlu dilakukan pengolahan menjadi tepung, dimana dapat dilakukan dengan pengeringan biasa. Namun, tepung porang yang diolah dengan proses pengeringan biasa memiliki warna dan aroma yang tidak disukai, yakni berwarna kecoklatan
Pro Food (Jurnal Ilmu dan Teknologi Pangan)

Vol 6 No. 2 November 2020

ISSN: 2443-1095

dan masih beraroma porang sehingga diperlukan alternatif pengolahan. Pengolahan alternatif lain yang dapat dilakukan yaitu memodifikasi karakter umbi porang seperti dalam pembuatan MOCAF (Modified cassava flour) melalui proses fermentasi.

Prinsip dari proses fermentasi pembuatan tepung umbi adalah memodifikasi sel umbi dengan bantuan mikroba yang dapat menghancurkan dinding sel umbi dengan enzim yang dihasilkan, sehingga terjadi hidrolisis pati menjadi gula selanjutnya diubah menjadi asamasam organik terutama berupa asam laktat. Hal ini menyebabkan tepung yang dihasilkan memiliki karakteristik yang lebih baik, yakni meningkatnya viskositas, daya rehidrasi, dan kemudahan melarut serta dapat menutupi cita rasa spesifik umbi sampai $70 \%$ sehingga cita rasa tepung yang dihasilkan menjadi netral (Nusa, 2012).

Menurut Sopandi (2014) pembuatan tepung fermentasi dapat dilakukan dengan fermentasi spontan dan fermentasi dengan starter. Fermentasi spontan dilakukan dengan bantuan mikroba yang secara alami berkembang biak karena lingkungan hidupnya sesuai dengan pertumbuhannya. Umumnya waktu fermentasi secara spontan antara 42 sampai 72 jam dan mikroba yang berperan adalah termasuk bakteri asam laktat seperti Acetobacter aceti, Acetobacter xylinum, Streptococcus termophilus dan Lactobacillus plantarum (Urbaya, 2017). Sedangkan fermentasi dengan starter dilakukan mikroba yang secara sengaja ditambahkan dalam bentuk starter yang tumbuh dan berkembang biak secara aktif merubah bahan pangan yang difermentasi. Starter yang ditambahkan merupakan satu atau lebih jenis mikroba yang berperan seperti pada fermentasi spontan. Mikroba yang dapat ditambahkan salah satunya jenis Lactobacillus plantarum. Bakteri $L$. plantarum umumnya lebih tahan terhadap keadaan asam dan oleh karenanya menjadi lebih banyak terdapat pada tahapan terakhir dari fermentasi tipe asam laktat. Bakteri $L$. plantarum terutama berguna untuk pembentukan asam laktat, penghasil hidrogen peroksida tertinggi dibandingkan bakteri asam 
Versi Online:

http://www.profood.unram.ac.id/index.php/profood e-ISSN: 2443-3446

laktat lainnya dan juga menghasilkan bakteriosin bersifat bakterisidal (Salminen, 1993).

Menurut penelitian Rahmawati (2015) menunjukkan bahwa penambahan starter $L$. plantarum konsentrasi 2\% (v/v) merupakan perlakuan terbaik pada fermentasi tepung ubi jalar kuning yang berpengaruh nyata terhadap parameter total $\mathrm{BAL}$, total asam, nilai $\mathrm{pH}$, serat kasar, gula reduksi, total gula, total nitrogen dan kadar pati. Senada dengan hasil penelitian Nurani (2013), diperoleh tepung talas modifikasi terbaik yakni modifikasi dengan menggunakan $L$. plantarum dengan konsentrasi $10 \%$ selama 48 jam yang menyebabkan kenaikan kadar pati $(14,32 \%)$ dan penurunan kadar serat kasar (35,34\%). Selain itu, menurut hasil penelitian Kurniati (2012) menyatakan $L$. plantarum dengan konsentrasi $5-15 \%$ pada pembuatan MOCAF menghasilkan hasil terbaik yakni dapat meningkatkan kadar protein dan menurunkan kadar HCN pada tepung MOCAF serta karakteristik fisik hampir menyerupai tepung terigu. Sedangkan menurut hasil penelitian Urbaya (2017) menyatakan bahwa pemberian konsentrasi $L$. plantarum $20 \%$ pada pembuatan tepung gadung merupakan perlakuan terbaik yaitu nilai $\mathrm{pH} 4,19$, kadar pati $14,49 \%$, rendemen $6,88 \%$, total bakteri asam laktat 6,9 Log CFU/g serta warna dan aroma yang disukai oleh panelis.

Berdasarkan uraian diatas maka telah dilakukan penelitian tentang Pengaruh Konsentrasi Starter Bakteri Lactobacillus plantarum Terhadap Beberapa Komponen Mutu Tepung Porang (Amorphophallus oncophyllus).

\section{BAHAN DAN METODE}

\section{Bahan dan Alat}

Bahan-bahan yang digunakan adalah umbi porang dengan varietas lokal yang diperoleh dari Dusun Banjar Getas Kecamatan Wanasaba Kabupaten Lombok Timur, suspensi Lactobacillus plantarum, air mineral, garam, aquades, buffer fosfat, media deMan Rogosa Sharpe Agar (MRSA), media deMan Rogosa Sharpe Broth (MRSB), alkohol 70\%, $\mathrm{H}_{2} \mathrm{SO}_{4}$ pekat $(95-97 \%), \mathrm{H}_{3} \mathrm{BO}_{3} 4 \%, \mathrm{HCL}$, dan larutan $\mathrm{Na}_{2} \mathrm{~S}_{2} \mathrm{O}_{3} 0,1$.

Alat-alat yang digunakan adalah baskom, stopwatch, botol UC, laminar air flow (STREAMLINE), vortex, blue tip, mikropipet, pengaduk, timbangan analitik (Kern), pH meter (Schott), tabung reaksi, erlenmeyer $250 \mathrm{~mL}, \mathrm{~L}$, labu ukur $1.000 \mathrm{~mL}$, aluminium foil, alat titrasi, pipet tetes, pemanas balik, saringan 80 mesh, hotplate (IEC), magnetic stirrer, sentrifugasi, gelas beker $500 \mathrm{~mL}$, gelas beker $1.000 \mathrm{~mL}$, pipet volume $10 \mathrm{~mL}$, pipet volume $25 \mathrm{~mL}$, pipet ukur $10 \mathrm{~mL}$, pipet ukur $5 \mathrm{~mL}$ plastik, blender, oven (Memmert), cabinet dryer, pengayak 80 mesh, kertas label dan tisu.

\section{Metode}

Metode yang digunakan dalam penelitian ini adalah metode eksperimental yang dilaksanakan di laboratorium.

\section{Pelaksanaan penelitian:}

\section{Preparasi Inokulum Bakteri Asam Laktat}

(Setiarto, 2016 dimodifikasi)

1. Peremajaan

Isolat BAL diremajakan pada media MRSB mengandung pati $(10 \% \mathrm{~b} / \mathrm{v})$ sebagai sumber karbon. Proses ini bertujuan untuk memperbanyak jumlah mikroorganisme yaitu kali ini menggunakan Lactobacillus plantarum.

2. Penginkubasian

Proses ini bertujuan agar isolat Lactobacillus plantarum mendapatkan kondisi yang sesuai untuk pertumbuhannya, dimana penginkubasikan dilakukan pada suhu $37^{\circ} \mathrm{C}$ selama 72 jam sehingga dihasilkan kultur murni.

3. Pemanenan

Setelah diikubasi selama 24 jam, selanjutnya dilakukan pemanenan kultur murni menggunakan jarum ose.

4. Perbanyakan kultur

Setelah dihasilkan kultur murni, kemudian ditumbuhkan pada medium MRSA untuk memperbanyak jumlah koloni starter hingga sesuai dengan jumlah yang dibutuhkan.

5. Isolat siap digunakan 
Versi Online:

http://www.profood. unram.ac.id/index.php/profood e-ISSN: 2443-3446

Perlakuan Sampel Umbi Porang (Urbaya, 2017 dimodifikasi)

1. Sortasi

Sebelum umbi porang diproses, sortasi dilakukan untuk memisahkan umbi porang yang rusak dan tidak memenuhi standar mutu.

2. Pencucian

Umbi porang yang telah dipilih dan memenuhi standar mutu kemudian dibersihkan dan dicuci untuk menghilangkan kontaminan fisik seperti tanah.

3. Perendaman air hangat

Perendaman dengan air hangat dengan suhu $40^{\circ} \mathrm{C}$ bertujuan untuk membuka poripori jaringan umbi sehingga senyawa seperti kalsium oksalat keluar dari jarinagn dalam umbi yang akan memudahkan poress menghilangkan kalsium.

4. Penirisan

Tahap ini dilakukan selama 15 menit bertujuan untuk menghilangkan kalsium oksalat yang terlarut dalam air peremdaman.

5. Pengecilan ukuran

Umbi porang yang telah bersih dan tiris kemudian dikecilkan ukurannya dengan pennyautan dengan ukuran kira-kira 1-1,5 $\mathrm{mm}$. Pengecilan ukuran juga bagian upaya untuk menghilangkan kalsium oksalat dan untuk mempermudah pengeringan.

6. Perendaman dengan air garam

Menurut Prabowo (2010) dalam penelitiannya dengan metode perendaman umbi porang didalam larutan garam $\mathrm{NaCl}$ $4,5 \%$ secara berulang ulang dan dapat mereduksi kalsium oksalat sebanyak $40 \%$.

7. Pencucian dan pembilasan

Pencucian dan pembilasan dilakukan setelah sawut porang mengalami perendaman dalam larurtan garam. Pencucian dan pembilasan dilakukan sebanyak 5 kali dan sawut di gosok perlahan kemudian direndam sebentar setelah itu ditiriskan. Tahap tersebut merupakan upaya untuk menghilangkan kalsium oksalat yang keluar akibat tekanan osmosis pada garam dan untuk menghilangkan kadar garam pada sawut porang sebelum diproses.
Pro Food (Jurnal Ilmu dan Teknologi Pangan) Vol 6 No. 2 November 2020 ISSN: 2443-1095

8. Proses fermentasi

Proses fermentasi dilakukan dengan metode fermentasi terendam pada suhu $25^{\circ} \mathrm{C}$ (suhu kamar) dengan ditutup plastik wrap kemudian diberikan parameter isolat bakteri asam laktat dengan konsentrasi yang berbeda $(0 \%, 5 \%, 10 \%, 15 \%, 20 \%$ dan $25 \%$ ) dan lama perendaman 48 jam.

9. Pencucian

Pencucian dilakukan setelah sawut porang mengalami fermentasi selama 48 jam menggunakan air biasa, bertujuan untuk membersihkan dan menghilangkan sisa BAL selama proses fermentasi.

10. Penirisan

Penirisan dilakukan selama 15 menit yang bertujuan untuk menghilangkan kadar air hasil pencucian dan mempermudah proses pengeringan.

11. Pengeringan

Setelah dilakukan penirisan selanjutnya dilakukan proses pengeringan menggunakan cabinet dryer dengan suhu kurang lebih $60^{\circ} \mathrm{C}$ selama kurang lebih 6 jam.

12. Penggilingan

Selanjutnya sawut porang yang telah kering digiling menggunakan blender untuk menghasilkan tepung porang fermentasi.

13. Pengayakan

Setelah sawut berubah menjadi tepung kemudian dilakukan pengayakan dengan ukuran ayakan 80 mesh (SNI 7622:2011) untuk menghasilkan tepung porang fermentasi yang halus.

\section{Rancangan Percobaan dan Analisis Data}

Rancangan yang digunakan pada penelitian ini adalah Rancangan Acak Lengkap (RAL) dengan percobaan faktor tunggal yaitu konsentrasi BAL (KB) jenis Lactobacillus plantarum dengan 6 perlakuan, yaitu:

$\mathrm{KB} 1=0 \%$ (Fermentasi Spotan)

$\mathrm{KB} 2=5 \%$ starter bakteri Lactobacillus plantarum

$\mathrm{KB} 3=10 \%$ starter bakteri Lactobacillus plantarum

KB4 $=15 \%$ starter bakteri Lactobacillus plantarum

KB5 $=20 \%$ starter bakteri Lactobacillus plantarum

$\mathrm{KB} 6=25 \%$ starter bakteri Lactobacillus plantarum 
Versi Online:

http://www.profood.unram.ac.id/index.php/profood e-ISSN: 2443-3446

Masing-masing perlakuan diulang sebanyak 3 kali sehingga diperoleh 18 unit percobaan. Data hasil pengamatan dianalisis menggunakan analisis keragaman (Analysis of Variance) pada taraf nyata $5 \%$ menggunakan software Co-stat. Apabila terdapat perbedaan nyata pada parameter kimia, fisik dan mikrobiologi, maka dilakukan uji lanjut Polynomial Orthogonal pada taraf $5 \%$. Sedangkan adanya perbedaan yang berbeda nyata antar perlakuan uji organoleptik, maka dilakukan uji lanjut Beda Nyata Jujur (BNJ) pada taraf $5 \%$.

\section{HASIL DAN PEMBAHASAN \\ Data hasil pengamatan dan analisis
pengaruh konsentrasi starter bakteri Lactobacillus plantarum terhadap beberapa komponen mutu yaitu nilai $\mathrm{pH}$, kadar protein, kadar air, rendemen, dan total BAL serta mutu organoleptik hedonik dan scoring tepung porang dapat dilihat dapat dilihat pada Tabel 1.}

Tabel 1. Signifikasi Pengaruh Konsentrasi Starter Bakteri Lactobacillus plantarum terhadap Tepung Porang

\begin{tabular}{lc}
\hline \multicolumn{1}{c}{ Parameter } & Signifikasi \\
\hline Nilai pH & $\mathrm{S}$ \\
Kadar Protein & $\mathrm{S}$ \\
Kadar Air & $\mathrm{NS}$ \\
Rendemen & $\mathrm{S}$ \\
Total BAL & $\mathrm{S}$ \\
Organoleptik: & $\mathrm{NS}$ \\
- Warna (hedonik) & $\mathrm{S}$ \\
- Aroma (hedonik) & $\mathrm{NS}$ \\
- Warna (scoring) & $\mathrm{S}$ \\
- Aroma (scoring) & Keterangan: $\mathrm{S}=$ Signifikan (berbeda nyata), NS= \\
Non Signifikan (tidak berbeda nyata)
\end{tabular}

\section{Nilai pH}

Konsentrasi starter bakteri Lactobacillus plantarum memberikan pengaruh yang berbeda nyata terhadap nilai $\mathrm{pH}$ tepung porang. Hubungan antara konsentrasi starter bakteri Lactobacillus plantarum dengan nilai $\mathrm{pH}$ tepung porang yang dihasilkan dapat dilihat pada Gambar 1.

Berdasarkan Gambar 1 menunjukkan bahwa semakin tinggi konsentrasi starter bakteri Lactobacillus plantarum maka nilai $\mathrm{pH}$ tepung porang yang dihasilkan semakin menurun dengan pola regresi linier dengan persamaan $y=-2,04 x+6,1867$ dengan koefisien determinasi $R^{2}=0,9182$. Nilai 2,04 merupakan nilai yang menunjukkan arah regresi linier yaitu bernilai negatif. Nilai negatif menunjukkan bahwa adanya hubungan yang negatif antara konsentrasi Lactobacillus plantarum terhadap nilai $\mathrm{pH}$ tepung porang. Hal ini berarti dengan semakin tinggi konsentrasi bakteri Lactobacillus plantarum akan menyebabkan penurunan nilai $\mathrm{pH}$ pada tepung porang sebesar 2,04.

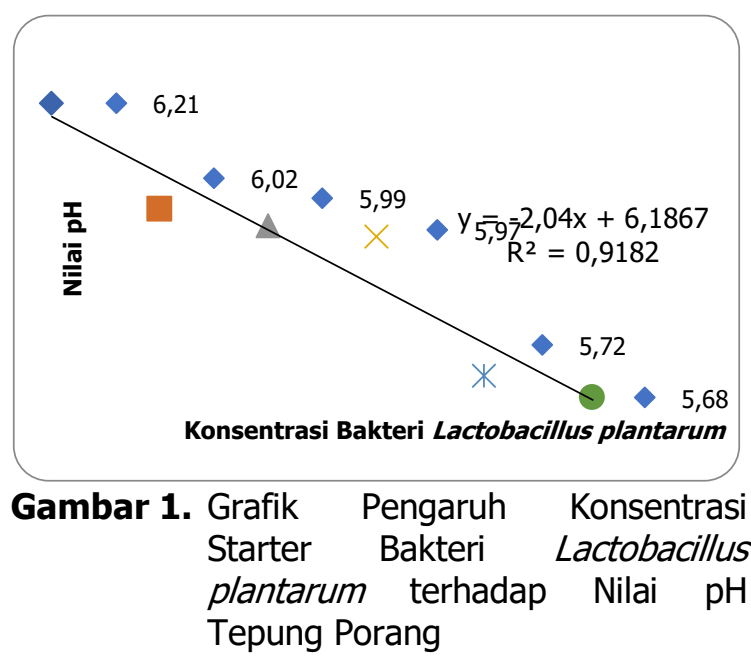

Nilai 6,1867 merupakan konstanta atau disebut intercept dimana pada titik $\mathrm{x}=0$, nilai $\mathrm{pH}$ sebesar 6,1867 . Nilai koefisien determinasi (KD) sebesar 0,9182 dikonversi ke dalam persen (\%) menjadi $91,8 \%$, artinya yaitu penurunan nilai $\mathrm{pH}$ tepung porang dipengaruhi sebesar $91,8 \%$ oleh konsentrasi starter bakteri Lactobacillus plantarum dan sisanya sebesar $8,2 \%$ dipengaruhi oleh faktor lain.

Penurunan $\mathrm{pH}$ pada tepung porang dengan semakin tinggi konsentrasi starter bakteri Lactobacillus plantarum yang disebabkan semakin tinggi bakteri, maka semakin tinggi jumlah bakteri Lactobacillus plantarum yang terdapat pada bahan sebagai mikroba awal. Selama fermentasi, terjadi pertumbuhan BAL karena jumlah populasi yang menghidrolisis pati menjadi gula yang selanjutnya diubah menjadi asam organik terutama asam laktat semakin banyak pula. Produksi asam dengan jumlah yang banyak 
Versi Online:

http://www.profood.unram.ac.id/index.php/profood e-ISSN: 2443-3446
Pro Food (Jurnal Ilmu dan Teknologi Pangan)

Vol 6 No. 2 November 2020

ISSN: 2443-1095 menyebabkan naiknya keasaman sehingga terjadi penurunana $\mathrm{pH}$ tepung porang yang dihasilkan. Hal ini sesuai dengan pendapat Kusmanto (2009) yang menyatakan bahwa mikroba yang tumbuh selama fermentasi akan menghasilkan enzim-enzim yang menghidrolisis pati menjadi gula yang selanjutnya diubah menjadi asam-asam organik, terutama berupa asam laktat. Menurut Rahmawati (2015) asam laktat dan asetaldehid yang dihasilkan dari pemecahan glukosa oleh bakteri Lactobacillus plantarum menyebabkan penurunan $\mathrm{pH}$ medium yang besar atau meningkatkan keasaman.

Senada dengan pendapat Surono (2004), selama proses fermentasi BAL mengubah glukosa menjadi asam laktat melalui jalur Embden Meyerhoff Parnas (EMP). Terakumulasinya asam laktat ini menyebabkan tingkat keasaman medium fermentasi akan meningkat. Pada media dengan sumber utama glukosa, asam laktat yang dihasilkan adalah sekitar 90\% dari produk akhir. Berbagai monosakarida dimetabolisme oleh bakteri asam laktat menjadi glucose-6-phosphate atau fructose-6-phosphate dan kemudian terjadi metabolisme melalui jalur Embden Meyerhoff Parnas (EMP) yang pada akhirnya dihasilkan asam laktat. Jumlah asam organik yang tinggi selama fermentasi dapat menyebabkan terjadinya penurunan derajat keasaman.

Penurunan $\mathrm{pH}$ merupakan salah satu akibat proses fermentasi yang terjadi karena adanya akumulasi asam laktat sebagai produk utama dari aktivitas bakteri yang bersifat homofermentatif yang terbentuk lebih banyak. Lactobacillus yang bersifat homofermentatif menghasilkan $90 \%$ asam laktat dari metabolisme glukosa. Penurunan $\mathrm{pH}$ semakin meningkat dengan meningkatnya total asam sebagai hasil metabolisme, dari meningkatnya bakteri Lactobacillus plantarum yang digunakan untuk fermentasi.

\section{Kadar Protein}

Konsentrasi starter bakteri Lactobacillus plantarum memberikan pengaruh yang berbeda nyata terhadap kadar protein tepung porang. Hubungan antara konsentrasi starter bakteri
Lactobacillus plantarum dengan kadar protein tepung porang yang dihasilkan dapat dilihat pada Gambar 2.

Berdasarkan Gambar 2. yang menunjukkan pengaruh konsentrasi starter bakteri L. plantarum terhadap kadar protein tepung porang bahwa semakin tinggi konsentrasi bakteri Lactobacillus plantarum maka kadar protein tepung porang yang semakin tinggi dengan pola regresi yang terbentuk yaitu kuadratik dengan persamaan y $=-49,214 x^{2}+21,018 x+4,3589$ dengan koefisien determinasi $R^{2}=0,9306$. Nilai 49,214 merupakan nilai yang menunjukkan arah regresi kuadratik yaitu bernilai negatif. Nilai negatif menunjukkan bahwa adanya hubungan yang negatif antara konsentrasi Lactobacillus plantarum terhadap kadar protein tepung porang. Hal ini berarti dengan semakin tinggi konsentrasi bakteri Lactobacillus plantarum akan menyebabkan penurunan kadar protein pada tepung porang. Pola kuadratik menunjukkan akan terjadi penurunana kadar protein apabila telah mencapai kadar protein pada konsentrasi starter bakteri tertentu. Sedangkan nilai 21,018 merupakan nilai yang menunjukkan arah regresi linier yaitu bernilai positif. Nilai positif menunjukkan bahwa adanya hubungan yang positif antara konsentrasi starter bakteri Lactobacillus plantarum terhadap kadar protein tepung porang. Hal ini berarti dengan semakin tinggi konsentrasi starter bakteri Lactobacillus plantarum akan menyebabkan peningkatan kadar protein pada tepung porang.

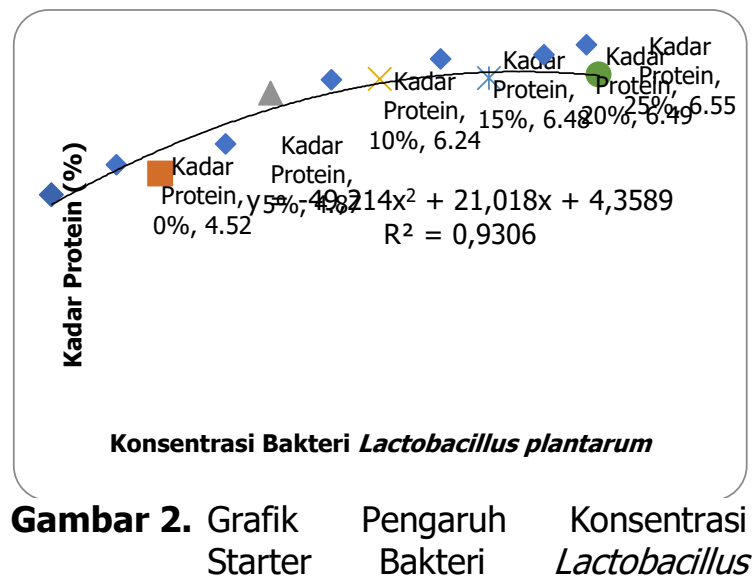


Versi Online:

http://www.profood.unram.ac.id/index.php/profood e-ISSN: 2443-3446

plantarum terhadap Kadar Protein Tepung Porang

Nilai 4,3589 merupakan konstanta atau disebut intercept dimana pada titik $\mathrm{x}=0$, kadar protein sebesar 4,3589. Nilai koefisien determinasi (KD) sebesar 0,9306 dikonversi ke dalam persen (\%) menjadi 93,06\%, artinya yaitu peningkatan kadar protein tepung porang dipengaruhi sebesar 93,06\% oleh konsentrasi starter bakteri Lactobacillus plantarum dan sisanya sebesar $6,94 \%$ dipengaruhi oleh faktor lain.

Peningkatan kadar protein pada tepung porang disebabkan karena dengan semakin meningkatnya konsentrasi starter bakteri Lactobacillus plantarum, maka enzim proteinase yang dibentuk selama fermentasi semakin banyak pula. Peningkatan enzim proteinase yang terbentuk akan berdampak pada peningkatan kadar protein tepung porang. Hal ini sesuai dengan pendapat Tandrianto (2014) yang menyatakan kenaikan kadar protein disebabkan karena selama fermentasi bakteri asam laktat Lactobacillus plantarum menghasilkan enzim proteinase. Adanya kenaikan kadar protein diperoleh dari aktivitas enzim protease yang dihasilkan oleh mikroba yang ada dalam proses fermentasi. Selain itu, menurut Tandrianto (2014) peningkatan jumlah protein juga disebabkan oleh adanya pertambahan jumlah mikroorganisme yang berperan sebagai Single Cell Protein (SCP), yaitu protein yang didapat dari mikroorganisme. Senada dengan pendapat Setiarto (2016) selama fermentasi BAL termasuk Lactobacillus plantarum akan menghasilkan peptidoglikan pada dinding selnya yang tersusun atas komponen glikoprotein dan lipoprotein. Komponen protein tersebut juga yang meningkatkan protein terkandung dalam tepung umbi termodifikasi dan teranalisis sebagai protein terlarut.

\section{Kadar Air}

Konsentrasi starter bakteri Lactobacillus plantarum memberikan pengaruh yang tidak berbeda nyata terhadap kadar air tepung porang. Hubungan antara konsentrasi starter bakteri Lactobacillus plantarum dengan kadar air tepung porang yang dihasilkan dapat dilihat pada Gambar 3.

Berdasarkan Gambar 3 menunjukkan bahwa konsentrasi starter bakteri Lactobacillus plantarum ditambahkan yang berbeda memberikan pengaruh yang tidak berbeda nyata terhadap kadar air tepung porang. Hasil ini diduga bahwa konsentrasi bakteri Lactobacillus plantarum $0 \%, 5 \%, 10 \%, 15 \%$, $20 \%$, dan $25 \%$ membutuhkan air yang tidak berbeda jauh untuk metabolisme selama proses fermentasi. Hal ini sesuai dengan pendapat Mardiani (2013) yang menyatakan selama proses fermentasi BAL membutuhkan air yang tidak berbeda jauh untuk metabolismenya. Selain itu air yang berdifusi ke dalam bahan selama proses fermentasi juga hampir sama karena jumlah air yang digunakan untuk perendaman pada saat fermentasi dan lama fermentasi yang sama.

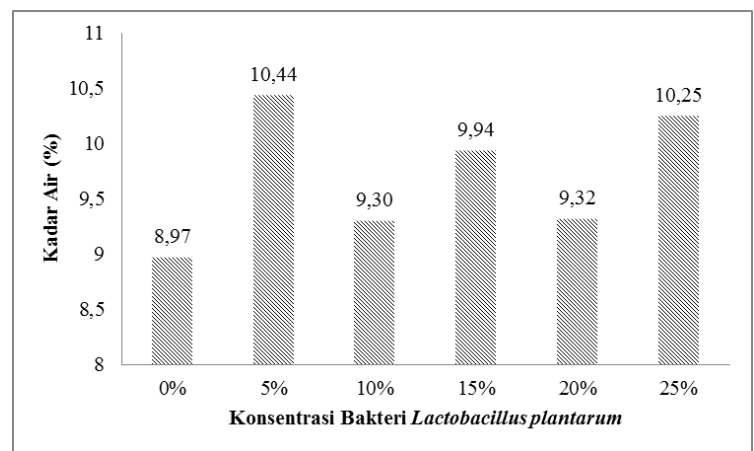

Gambar 3. Grafik Pengaruh Konsentrasi Starter Bakteri Lactobacillus plantarum terhadap Kadar Air Tepung Porang

Berdasarkan hasil analisis, kadar air tepung porang berkisar antara $8-11 \%$ yang artinya telah memenuhi Standar Nasional Indonesia 7622:2011 tentang standar tepung MOCAF yang kadar air maksimumnya $13 \%$.

\section{Rendemen}

Konsentrasi starter bakteri Lactobacillus plantarum memberikan pengaruh yang berbeda nyata terhadap rendemen tepung porang. Hubungan antara konsentrasi starter bakteri Lactobacillus plantarum dengan rendemen 
Versi Online:

http://www.profood.unram.ac.id/index.php/profood e-ISSN: 2443-3446

tepung porang yang dihasilkan dapat dilihat pada Gambar 4.

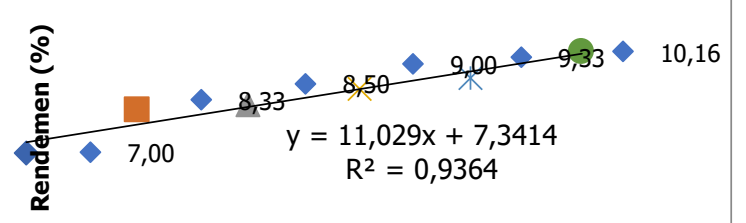

Konsentrasi Bakteri Lactobacillus plantarum

Gambar 4. Grafik Pengaruh Konsentrasi Starter Bakteri Lactobacillus plantarum terhadap Rendemen Tepung Porang

Berdasarkan Gambar 4 menunjukkan bahwa semakin tinggi konsentrasi starter bakteri Lactobacillus plantarum maka rendemen tepung porang semakin tinggi dengan pola regresi yang terbentuk yaitu linier dengan persamaan $\mathrm{y}=11,029 \mathrm{x}+7,3414$ dengan koefisien determinasi $R^{2}=0,9364$. Nilai 11,029 merupakan nilai yang menunjukkan arah regresi linier yaitu bernilai positif. Nilai positif menunjukkan bahwa adanya hubungan yang positif antara konsentrasi bakteri Lactobacillus plantarum terhadap rendemen tepung porang. Hal ini berarti dengan semakin tinggi konsentrasi starter bakteri Lactobacillus plantarum akan menyebabkan peningkatan rendemen pada tepung porang sebesar 11,029.

Nilai 7,3414 merupakan konstanta atau disebut intercept dimana pada titik $\mathrm{x}=0$, rendemen sebesar 7,3414. Nilai koefisien determinasi (KD) sebesar 0,9364 dikonversi ke dalam persen (\%) menjadi $93,6 \%$, artinya yaitu penurunan nilai $\mathrm{pH}$ tepung porang dipengaruhi sebesar $93,6 \%$ oleh konsentrasi starter bakteri Lactobacillus plantarum dan sisanya sebesar $6,4 \%$ dipengaruhi oleh faktor lain.

Peningkatan rendemen tepung porang dengan penambahan starter bakteri Lactobacillus plantarum disebabkan karena semakin banyak konsentrasi mikroba yang ditambahkan maka jumlah mikroba yang tumbuh selama fermentasi semakin tinggi sehingga pembentukan enzim oleh mikroba akan semakin banyak yang menyebabkan rendemen dari tepung yang dihasilkan semakin tinggi, dimana selama pertumbuhannya dapat menghasilkan enzim a-amilase yang dapat menghancurkan dinding sel dari umbi yang menyebabkan rusaknya jaringan dan memudahkan perpindahan senyawa-senyawa larut air. Terlarutnya senyawa-senyawa tersebut, masa tepung porang menjadi berkurang sehingga terjadinya peningkatan rendemen (Nusa, 2012).

\section{Total BAL}

Konsentrasi starter bakteri Lactobacillus plantarum memberikan pengaruh yang berbeda nyata terhadap total BAL tepung porang. Hubungan antara konsentrasi starter bakteri Lactobacillus plantarum dengan total BAL tepung porang yang dihasilkan dapat dilihat pada Gambar 5.

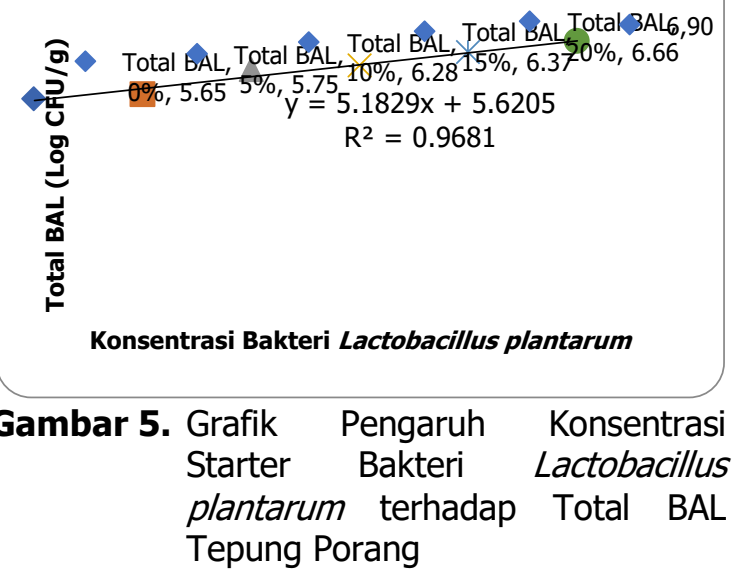

Berdasarkan Gambar 5 menunjukkan bahwa semakin tinggi konsentrasi starter bakteri Lactobacillus plantarum maka total BAL pada tepung porang semakin tinggi dengan pola regresi yang terbentuk yaitu linier dengan persamaan $\mathrm{y}=5,1829 \mathrm{x}+5,6205$ dengan koefisien determinasi $R^{2}=0,9681$. Nilai 5,1829 merupakan nilai yang menunjukkan arah regresi linier yaitu bernilai positif. Nilai positif menunjukkan bahwa adanya hubungan yang positif antara konsentrasi starter bakteri Lactobacillus plantarum terhadap total BAL tepung porang. Hal ini berarti dengan semakin tinggi konsentrasi starter bakteri Lactobacillus 
Versi Online:

http://www.profood.unram.ac.id/index.php/profood e-ISSN: 2443-3446

plantarum akan menyebabkan peningkatan total BAL pada tepung porang sebesar 5,1829.

Nilai 5,6205 merupakan konstanta atau disebut intercept dimana pada titik $\mathrm{x}=0$, total BAL sebesar 5,6205 . Nilai koefisien determinasi (KD) sebesar 0,9681 dikonversi ke dalam persen (\%) menjadi 96,8\%, artinya yaitu peningkatan total BAL tepung porang dipengaruhi sebesar $96,8 \%$ oleh konsentrasi bakteri Lactobacillus plantarum dan sisanya sebesar 3,2\% dipengaruhi oleh faktor lain.

Peningkatan total BAL yang semakin tinggi karena populasi BAL semakin banyak dengan semakin tingginya konsentrasi starter bakteri Lactobacillus plantarum yang ditambahkan. Selama fermentasi terjadi pertumbuhan BAL didukung oleh komponen bahan baku yang digunakan sebagai sumber nutrisi oleh BAL selama proses fermentasi seperti karbohidrat yang diubah menjadi energi. Energi tersebut digunakan untuk pertumbuhan sel sehingga semakin banyak energi yang dihasilkan akan menyebabkan terjadi kenaikan jumlah sel. Hal tersebut sesuai dengan pernyataan Rahmawati (2015) yang menyatakan bakteri asam laktat dalam medium akan memfermentasi atau menghidrolisis gula menjadi komponen-komponen yang lebih sederhana menjadi asam laktat, asam organik, $\mathrm{CO}_{2}, \mathrm{H}_{2} \mathrm{O}$ dan energi. Selanjutnya energi digunakan untuk sintesis sehingga terjadi kenaikan jumlah sel. Selain itu, dibuktikan dengan hasil uji $\mathrm{pH}$ yang menunjukkan semakin tinggi penambahan konsentrasi starter baktreri Lactobacillus plantarum maka menghasilkan $\mathrm{pH}$ yang semakin asam yang menunjukkan pertumbuhan Lactobacillus plantarum yang semakin tinggi.

\section{Warna}

Penambahan konsentrasi starter bakteri Lactobacillus plantarum $0 \%, 5 \%, 10 \%, 15 \%$, $20 \%$, dan $25 \%$ pada fermentasi tepung porang memberikan pengaruh tidak berbeda nyata warna tepung porang baik secara hedonik maupun scoring. Hubungan pengaruh konsentrasi starter bakteri Lactobacillus plantarum terhadap warna tepung porang baik secara hedonik dan scoring dapat dilihat pada Gambar 6.

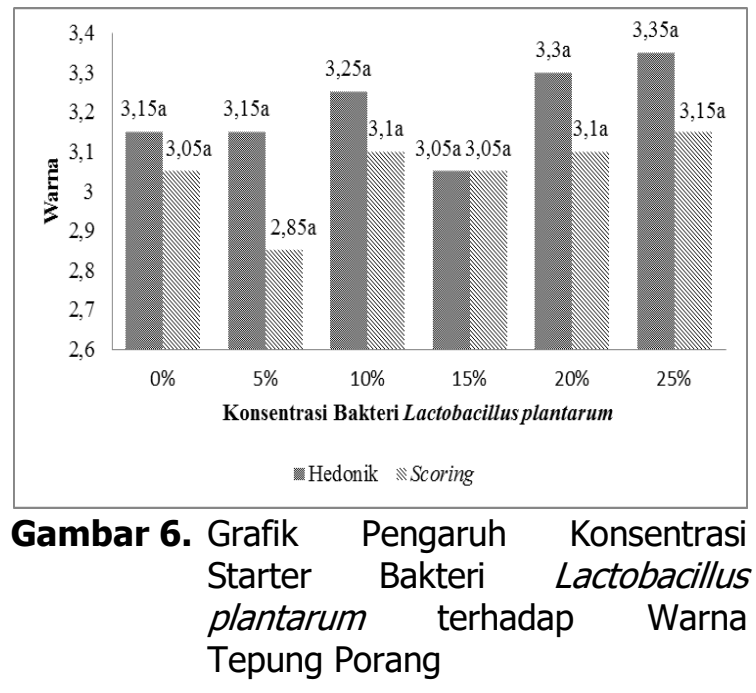

Berdasarkan Gambar 6 menunjukkan bahwa konsentrasi starter bakteri Lactobacillus plantarum $0 \%, 5 \%, 10 \%, 15 \%, 20 \%$, dan $25 \%$ menghasilkan hasil yang tidak berbeda nyata baik secara hedonik dan scoring terhadap warna tepung porang yaitu agak kecoklatan. Hal ini disebabkan karena pada semua perlakuan melalui proses fermentasi yang sama, sehingga pada perlakuan $0 \%, 5 \%, 10 \%$, $15 \%$, 20\%, dan $25 \%$ terjadi hidrolisis komponen penyusun warna oleh adanya aktivitas mikroba Lactobacillus plantarum selama proses fermentasi 48 jam baik secara alami maupun penambahan kultur murni Lactobacillus plantarum adalah relatif sama.

Penambahan bakteri Lactobacillus plantarum tidak berpengaruh nyata terhadap warna tepung porang yang dihasilkan, diduga disebabkan karena enzim pektinase dan sellulase serta a-amilase yang dihasilkan oleh BAL Lactobacillus plantarum berfungsi untuk merusak dinding sel sehingga warna yang dihasilkan seperti warna asli dari umbi porang yaitu berwarna kecoklatan. Selain itu menurut Wardhani (2017), umbi porang mengandung karoten mencapai $40 \mathrm{mg} / \mathrm{kg}$ dan mengandung enzim polyphenol oxsidase (PPO) serta senyawa polifenolik termasuk tannin. Senyawa yang terkandung dalam umbi porang itulah yang menyebabkan warna tepung porang yang dihasilkan masih agak coklat. Hal tersebut 
Versi Online:

http://www.profood.unram.ac.id/index.php/profood e-ISSN: 2443-3446

disebabkan karena meskipun melalui proses pengeringan dengan menggunakan suhu $60^{\circ} \mathrm{C}$, enzim polyphenol oxsidase akan tetap bekerja dimana enzim tersebut dapat bekerja hingga suhu $70^{\circ} \mathrm{C}$ sehingga tepung porang berwarna agak cokelat.

\section{Aroma}

Penambahan konsentrasi starter bakteri Lactobacillus plantarum $0 \%, 5 \%, 10 \%, 15 \%$, $20 \%$, dan $25 \%$ pada fermentasi tepung porang memberikan pengaruh berbeda nyata terhadap aroma tepung porang secara hedonik dan scoring. Hubungan pengaruh konsentrasi bakteri Lactobacillus plantarum terhadap aroma tepung porang baik secara hedonik dan scoring setelah dilakukan uji lanjut menggunakan uji Beda Nyata Jujur (BNJ) pada taraf nyata 5\% dapat dilihat pada Gambar 7.

Berdasarkan Gambar 7 menunjukkan pengaruh konsentrasi starter bakteri $L$. plantarum terhadap aroma tepung porang yang dihasilkan bahwa rata-rata panelis memberikan nilai aroma tepung porang terhadap tingkat kesukaan (hedonik) berkisar antara 2,5-3,65 (tidak suka sampai agak suka) dengan nilai tertinggi yaitu perlakuan dengan konsentrasi starter bakteri Lactobacillus plantarum 25\% dengan kriteria agak disukai disebabkan semakin banyaknya jumlah bakteri Lactobacillus plantarum yang dapat menghasilkan asam dalam jumlah banyak sehingga dapat menutupi aroma khas porang yang tidak disukai panelis dan terendah pada perlakuan dengan konsentrasi starter bakteri Lactobacillus plantarum $0 \%$ dengan krieria tidak disukai disebabkan sedikitnya jumlah bakteri Lactobacillus plantarum yang dapat menghasilkan asam sehingga asam yang dihasilkan dalam jumlah sedikit yang tidak dapat menutupi aroma khas porang yang tidak disukai panelis. Sedangkan berdasarkan tingkat penilaian (scoring) rata-rata panelis memberikan nilai aroma tepung porang pada rentang 2,6-3,55 (tidak asam sampai agak asam) dengan nilai tertinggi sebesar 3,55 yaitu perlakuan dengan konsentrasi bakteri Lactobacillus plantarum $25 \%$ dengan kriteria beraroma agak asam karena asam yang
Pro Food (Jurnal IImu dan Teknologi Pangan)

Vol 6 No. 2 November 2020

ISSN: 2443-1095

dihasilkan bakteri Lactobacillus plantarum dalam jumlah yang lebih banyak dibandingkan konsentrasi starter bakteri Lactobacillus plantarum $0 \%, 5 \%, 10 \%, 15 \%, 20 \%$ dan terendah sebesar 2,6 pada perlakuan dengan konsentrasi bakteri Lactobacillus plantarum $0 \%$ dengan kriteria beraroma tidak asam karena asam yang dihasilkan bakteri Lactobacillus plantarum dalam jumlah yang lebih sedikit dibandingkan konsentrasi starter bakteri Lactobacillus plantarum 5\%, 10\%, 15\%, 20\%, dan $25 \%$.

Data hasil sensori aroma tepung porang secara hedonik yaitu semakin banyak konsentrasi bakteri Lactobacillus plantarum maka penilaian panelis terhadap aroma tepung porang semakin meningkat yang berarti semakin disukai panelis, tertinggi pada perlakuan konsentrasi bakteri Lactobacillus plantarum $25 \%$ tidak berbeda nyata dengan konsentrasi $15 \%$ dan $20 \%$ namun berbeda nyata dengan konsentrasi $0 \%, 5 \%$, dan $10 \%$. Sedangkan hasil sensori aroma tepung porang secara scoring semakin tinggi konsentrasi bakteri Lactobacillus plantarum maka aroma yang dihasilkan semakin asam, tertinggi $25 \%$ tidak berbeda nyata dengan perlakuan konsentrasi $5 \%$, 10\%, $15 \%$, dan $20 \%$ namun berbeda nyata dengan konsentrasi $0 \%$.

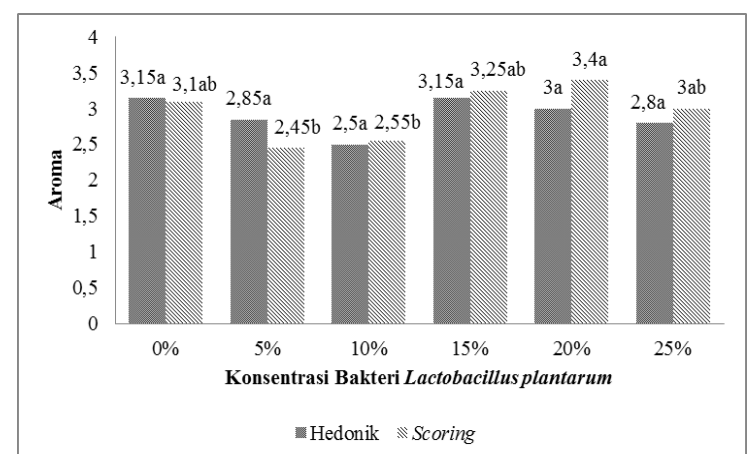

Gambar 7. Grafik Pengaruh Konsentrasi Bakteri Lactobacillus plantarum terhadap Aroma Tepung Porang

Semakin tinggi penambahan konsentrasi bakteri Lactobacillus plantarum maka tepung porang yang dihasilkan semakin beraroma asam sehingga aroma khas porang juga semakin tidak ada (hilang). Hal tersebut sesuai dengan pendapat Armanto (2008), 
Versi Online:

http://www.profood.unram.ac.id/index.php/profood e-ISSN: 2443-3446

semakin tinggi konsentrasi bakteri asam laktat maka asam laktat yang dihasilkan juga semakin meningkat, sehingga menyebabkan bau asam pada produk pati singkong yang dihasilkan. Senada dengan pendapat Suhery (2015) pada proses fermentasi bakteri asam laktat akan menimbulkan bau asam akibat dari produksi asam laktat. Bau asam tersebut diakibatkan karena adanya konversi karbohidrat selama fermentasi. Bau asam inilah yang dapat mengurangi bau dari talas, tepung termodifikasi memiliki sedikit bau khas bahan baku dibanding tepung yang dibuat tanpa proses fermentasi.

Menurut Surono (2004), selama proses fermentasi BAL mengubah glukosa menjadi asam laktat melalui jalur Embden Meyerhoff Parnas (EMP). Pati yang terkandung akan dipecah menjadi glukosa yang selanjutnya akan mengalami proses glikolisis sehingga menjadi asam piruvat. Asam piruvat mengalami proses fermentasi karena tidak tersedianya oksigen (anaerob). Hasil akhir dari serangkaian proses tersebut berupa asam laktat apabila mikroba yang berperan berupa bakteri, sedangkan apabila mikroba yang berperan mikroba jenis khamir maka akan manghasilkan alkohol berupa etanol atau biasa disebut dengan fermentasi alkoholik.

\section{KESIMPULAN}

Berdasarkan hasil analisa serta uraian pembahasan yang terbatas pada lingkup penelitian ini ditarik kesimpulan sebagai berikut:

1. Perlakuan konsentrasi starter bakteri Lactobacillus plantarum memberikan pengaruh yang berbeda nyata terhadap nilai $\mathrm{pH}$, kadar protein, rendemen, total BAL, dan organoleptik aroma (scoring) tepung porang, namun memberikan pengaruh yang tidak berbeda nyata terhadap kadar air serta mutu organoleptik warna (hedonik dan scoring) dan aroma (hedonik) tepung porang.

2. Semakin tinggi konsentrasi starter bakteri Lactobacillus plantarum maka tepung porang yang dihasilkan memiliki kadar protein, rendemen, total BAL dan aroma
Pro Food (Jurnal Ilmu dan Teknologi Pangan) Vol 6 No. 2 November 2020 ISSN: 2443-1095

asam semakin tinggi pula. Namun semakin tinggi konsentrasi starter bakteri Lactobacillus plantarum tepung porang yang dihasilkan memiliki $\mathrm{pH}$ yang semakin menurun.

3. Perlakuan dengan pemberian konsentrasi strater bakteri Lactobacillus plantarum $20 \%$ merupakan perlakuan terbaik berdasarkan SNI tepung MOCAF 7622:2011 dalam menghasilkan tepung porang, yaitu nilai $\mathrm{pH}$ 5,72 , kadar protein 6,49\%, rendemen 9,33\%, total bakteri asam laktat 6,66 CFU/g serta warna agak coklat dan aroma agak asam serta agak disukai panelis.

\section{DAFTAR PUSTAKA}

Armanto, R. dan A. S. Nurasih. 2008. Kajian Konsentrasi Bakteri Asam Laktat dan Lama Fermentasi pada Pembuatan Tepung Pati Singkong Asam. Jurnal AGRITECH. 28 (3): 97-101.

Harijati, N., E.L. Arumingtyas, dan R. Handayani. 2011. Pengaruh Pemberian Kalsium terhadap Ukuran dan Kerapatan Kristal Kalsium Oksalat pada Porang (Amorphophallus muelleri blume). Jurnal Pangan dan Agroindustri. 1(2): 72-139.

Koswara, S. 2006. Iles-iles dan hasil olahannya. E-book pangan.com.

Koswara, S. 2013. Teknologi Pengolahan UmbiUmbian. IPB-Press. Bogor.

Kurniati, L.I., N. Aida., S. Gunawan dan T. Widjaja. 2012. Pembuatan MOCAF (Modified Cassava Flour) dengan Proses Fermentasi menggunakan Lactobacillus plantarum, Saccharomyces cerevisiae, dan Rhizopus oryzae. Jurnal Teknik POMITS. 1 (1): 1-6.

Kusmanto. 2009. Total Bakteri dan Sifat Organoleptik Minuman Sari Tempe dengan Variasi Waktu Penyimpanan. Skripsi. Universitas Muhammadiyah Semarang. Semarang.

Mardiani, A., J. Sumarmono., dan T. Setyawardani. 2013. Total Bakteri Asam Laktat Kadar Air, dan Protein Keju Peram Susu Kambing yang Mengandung Probiotik Lactobacillus casei dan Bifidobacterium longum. 
Versi Online:

http://www.profood.unram.ac.id/index.php/profood e-ISSN: 2443-3446

Jurnal Ilmiah Peternakan. 1 (1): 244253.

Nurani, D., S. Sukotjo dan I. Nurmalasari. 2013. Optimasi Proses Produksi Tepung Talas (Colocasia esculenta, L. Schott) Termodifikasi secara Fermentasi. Jurnal IPTEK. 8 (1): 65-71.

Nusa, M. I., B. Suarti dan Alfiah. 2012. Pembuatan Tepung MOCAF melalui Penambahan Starter dan Lama Fermentasi (Modified Cassava Flour). Jurnal Agrium. 17 (3): 210-217.

Ohtsuki, T. 1968. Studies on Reserve Carbohydrates of Flour Amorphophallus Spicies with Special Refrence to Mannan. Journal Botanical Magazine. 81 (1): 119-126.

Prabowo, A. 2010. Frekuensi Penggunaan Larutan Garam Secara Berulang Pada Proses Penurunan Kandungan Kalsium Oksalat Chips Porang. Skripsi. Universitas Brawijaya. Malang.

Rahmawati, I. S., E. Zubaida, dan E. Saparianti. 2015. Evaluasi Pertumbuhan Isolat Probiotik (L. casei dan L. plantarum) dalam Medium Fermentasi Berbasis Ubi Jalar (Ipomoea batatas L.) selama Proses Fermentasi (Kajian Jenis Isolat dan Jenis Tepung Ubi Jalar). Jurnal Aplikasi Teknologi Pangan. 4 (4): 133141.

Salminen, S and A. V. Wright. 1993. Lactic Acid Bacteria: Microbiology and Functional Aspects. Marcel Dekker Inc. New York.

Santosa, E., 2014. Pengembangan Tanaman Iles-Iles Tumpangsari Untuk Kesejahteraan Petani dan Kemandirian Industri Pangan Nasional. Jurnal Risalah Kebijakan Pertanian dan Lingkungan. 1(2): 73-79.

Setiarto, R. H. B. dan N. Widhyastuti. 2016. Pengaruh Fermentasi Bakteri Asam Laktat Lactobacillus plantarum B307 Terhadap Kadar Proksimat dan Amilografi Tepung Taka Modifikasi (Tacca leontopetaloides). Jurnal Ilmu Pertanian Indonesia (JIPI). 21 (1): 717.

SNI. 2011. Tepung MOCAF. SNI 7622-2011. Badan Standarisasi Nasional. Jakarta.
Pro Food (Jurnal Ilmu dan Teknologi Pangan)

Vol 6 No. 2 November 2020

ISSN: 2443-1095

Sopandi, Tatang dan Wardah. 2014. Mikrobiologi Pangan dan Pengolahan: Teori dan Praktikum. Yudhistira. Yogyakarta.

Sudarmadji. S., Haryono dan Suhardi, 1997. Prosedur Analisa untuk Bahan Makanan dan Pertanian. Liberty. Yogyakarta.

Suhery, W. N., D. Anggraini dan N. Endri. 2015. Pembuatan dan Evaluasi Pati Talas (Colocasia esculenta Schoot) Termodifikasi dengan Bakteri Asam Laktat (Lactobacillus sp.). Jurnal Sains Farmasi \& Klinis. 1(2): 207-214.

Surono, I. S. 2004. Probiotik Susu Fermentasi dan Kesehatan. YAPMMI.TRICK. Jakarta.

Tandrianto, J., D. K. Mintoko., dan S. Gunawan. 2014. Pengaruh Fermentasi pada Pembuatan Mocaf (Modified Cassava Flour) dengan Menggunakan Lactobacillus plantarum terhadap Kandungan Protein. Jurnal Teknik POMITS. 3 (2): 143-145.

Urbaya, L. N., Nazaruddin dan W. Werdiningsih. 2017. Pengaruh Konsentrasi Lactobacillus plantarum Terhadap Mutu Tepung Gadung (Discorea hispida Dennst). Jurnal Ilmu dan Teknologi Pangan. 1 (1): 1-13.

Wardhani, D. H., A. A. Atmadja, dan C. R. Nugraha. 2017. Pencegahan Pencoklatan Enzimatik pada Porang Kuning (Amorphophallus oncophyllus). Jurnal Reaktor. 17 (2): 104- 110

Yuzammi. 2009. The Genus Amorphophallus Blume ex Decaisne (AraceaeThomsonieae) in Java. LIPI. Indonesia. 